\title{
Study of Religion in Modern Russian Education System: Problems and Prospects*
}

\author{
Vladimir Tsvyk \\ Faculty of Humanities and Social Sciences \\ Peoples' Friendship University of Russia \\ 6 Miklukho-Maklaya Street \\ Moscow, Russia \\ E-mail: tsvyk_va@university.ru
}

\author{
Irina Tsvyk \\ Department of Philosophy \\ Moscow Aviation Institute \\ Moscow, Russia \\ E-mail: tsvykirina@mail.ru
}

\begin{abstract}
This paper investigates the problem of studying religious disciplines in the system of modern Russian education. The study of religion in modern Russian schools and universities is noted to be essential for the comprehensive development of the individual. However, this requires a balanced approach. The authors' point of view is that in state educational institutions only religious studies, not theological education, are possible; they will inform the youth on the history of world religions, their dogmas, traditions and today's life of religious communities from scientific and objective positions.
\end{abstract}

Keywords-modern education; religious education; religious studies; secular state; history of religion

\section{INTRODUCTION}

The humanistic, harmonious development of the human personality is the strategic goal of spiritual production, a powerful branch of which is the education system. Education is a well-established process of transferring, processing and obtaining knowledge in the course of systematically organized training of a group of people over a certain period of time. Thanks to the existence of the institution of education, people for many centuries adopt the vast experience of knowledge and skills accumulated by civilization for all of its existence. Purposeful activity of people in obtaining and improving skills and knowledge for expanding the boundaries of knowledge is the main driving force of scientific and technological progress. In this context, it is very important to define the content boundaries of the very concept of "education". "Education is: a) a social institution whose main function is to prepare and incorporate the individual into various spheres of life of the society; b) the set of systematized knowledge, skills (especially professional ones) acquired by the individual (independently or in the process of training in special educational institutions); c) the process of mastering knowledge, i.e. education; d) the level of education of an individual with versatile knowledge and a high degree of culture; e) the education of society, the people, as a level of civilization of the country" [1]. It should be noted that in all these cases, it

*The publication was prepared with the support of the "RUDN University Program 5-100". is decisive to consider education not only in its educational context, but mainly as "education", "creation" of the individual [2].

The Law on Education of the Russian Federation states that "education is a single purposeful process of educating and training, which is a socially significant benefit and is carried out in the interests of the individual, the family, the society and the state, as well as the totality of acquired knowledge, skills, values, and the competence of a certain amount and complexity for the purposes of intellectual, spiritual, moral, creative, physical and (or) professional development of a person, the satisfaction of his educative needs and interests" [3].

Within the framework of this approach, "education" refers exclusively to the individual, to the person and can be considered as creating a person's image of the surrounding world and the person himself, his "I" in this world. However, education performs an important creative function not only in relation to the individual, but also in relation to the society as a whole. The moral potential of education is determined by its status as a social and political institution. It is a universal moral way of life for the people, serves to strengthen its statehood, the development of history and culture, language, the formation of spiritual and moral values. Thanks to this, a person-citizen is formed, the personality is integrated into the system of poly-ethnic cultures, and society, through education, special ethics of life, creates itself, based on adequate forms of pedagogical and social activity [4]. One of the important components of the educational direction of modern educational process is the study of various forms of spiritual culture, including religion. The history of religion shows its closest connection with the development of society, both with changes in its structure and principles of organization, and with the spiritual and moral development of man.

To denote educational activities related to the study of religion, two concepts are most commonly used: "religious education" and "religious studies". They are united by the subject of study - religion as a type of the worldview of an individual, a special sphere of culture and social life. Religious studies began to develop actively in our country only in the last decade of the 20th century, proceeding from 
their basis in the past - the system of atheistic education. This led to the existence of a number of approaches to the study of religion of a different ideological orientation. In pedagogical academic school and high school practice, the direction of the culturological representation of religions is actively developing today within the framework of the civilizational approach.

With Religious education the situation is even more complicated. During the Soviet period, the study of religion was carried out only in theological seminaries and academies. With the development of the sphere of non-state education, private educational institutions, schools of religious organizations have appeared; religious institutions have been opened and are functioning as institutions of higher professional education. Despite the fact that their founders are religious organizations, they are preparing for a number of quite secular specialties (for the time being, mainly, humanitarian). The question arises, in this case, is this religious or secular education? If it's religious, then why is literature, history, languages and even economics or natural science studied? If it is secular, then why is teaching conducted on a religious worldview basis and with the participation of representatives or organizations of religious confessions? All this actualizes the problem of scientific comprehension of the study of religion in society in its entirety, of a systematic analysis of the content, features and interrelations of all types and forms of religious education and religious studies. Such a comprehension, in our opinion, will allow to implement the state policy in the field of education more effectively.

\section{RELIGIOUS EDUCATION IN THE MODERN RUSSIAN SOCIETY: FORMS AND METHODS}

The secularity of the state and the public school, according to Russian legislation, suggests that "the Russian Federation is a secular state. No religion can be established as state or mandatory" (Article 14 of the Constitution of the Russian Federation) and that, accordingly, education in state and municipal educational institutions is secular (Paragraph 6, Article 3 of the Law of the Russian Federation "On Education" and Paragraph 2, Article 4 of the Federal Law "On Freedom of Conscience and on Religious Associations") [5].

The principle of secularism is revealed in the negative formulation: "it cannot be established as ... compulsory". In a literal sense, this means only that in the Russian state system of education there cannot be compulsory for all students to study a particular religion.

It should be emphasized that the secularity of education does not mean its atheism, but it assumes its independence from the pressure of religious structures or ideology, and, moreover, from direct subordination of educational activity to religious communities. In our opinion, the secular nature of the state education system implies compliance with the following criteria:
- The inadmissibility of establishing any religion or ideology (including atheistic) as compulsory in state educational institutions;

- Non-interference of religious associations in the management of public educational institutions;

- Ensuring the rights of students and teachers to freedom of conscience;

- Inadmissibility of coercion in the teaching of religion.

Most states in the modern world are secular, and at the same time almost everywhere the state system of education provides for the possibility of studying one or another religion of choice. As for the differences in the content and forms of religious education, the relevant problems are solved by legal means (contracts, agreements, etc.) that establish the sphere of interaction, division of functions and powers in the state system of education of government bodies (at the central, regional and local levels) with the governing bodies of religious organizations. In the sphere of joint competence of the state and religious organizations, all private interests of the participants in the educational process are observed in the practice of studying religion, but the priority is given to the nation-wide.

So, secular is any education aimed at solving various social tasks, organized and supported by society through state authorities and local self-government. Secular education is organized and conducted in accordance with the norms and requirements of state educational standards, considering the diversity of worldview approaches.

The main types of modern secular education are preschool education, general education, vocational education, additional education, continuing education in various areas and specialties, demanded by society. Organizations of religious confessions in educational institutions established or created with their participation implement secular educational programs of various types, levels and orientations in accordance with state educational standards, as well as programs of religious education in accordance with the educational programs adopted in these institutions, insofar as they relate to the competence of the educational institution. The realization in such educational institutions of the secular content of education in accordance with state educational standards is provided by the state and appropriately checked and controlled (licensing, accreditation).

Along with such educational institutions, there are special educational institutions of religious confessions theological schools in the Russian Orthodox Church (theological academies, seminaries), the schools of worshipers in other religious denominations, where the training of persons necessary for the administration of this religious cult is carried out. Spiritual educational organizations are established in accordance with the procedure established by the legislation of the Russian Federation on freedom of conscience, freedom of religion and on religious associations. 
Professional religious (spiritual) education includes special training, which, being significant for members of this religious organization, followers of this religion, has no general social significance. This training is focused on the inner spiritual life of the religious community, carried out in different conditions than the development of secular educational programs, and is not regulated by state educational standards for several parameters [6]. First, with respect to the content of education and the conditions for obtaining it (the procedure for enrolling students, the choice of forms of instruction, the rights of participants in the educational process, etc.). At the same time, the education in the spiritual schools is not limited to the preparation necessary solely for the administration of a religious cult, as will be specifically mentioned below.

Thus, it is obvious that religious education as a whole is broader than professional religious (spiritual) education as such. But how does it relate to secular education? Let us distinguish three qualitative features of educational activity in society in connection with the study of religion, which will help us to understand the content of the concept of "religious education":

- Organizational and legal affiliation of educational activities - educational institution, educational practice in any other form to a religious organization (confession);

- The content of education, educational activities, i.e. what, in fact, is being studied, what knowledge is taught and mastered;

- World outlook religious basis of educational activity, educational or educational process.

Religious education by organizational affiliation is carried out in organizations and institutions of the Russian Orthodox Church (church education), in Islamic, Buddhist, Judaic and other religious organizations and institutions, i.e. that are established by religious organizations independently or jointly with other founders and are recognized or controlled by them in any way. Religious education in content is carried out in order to increase the volume, level and quality of human knowledge about a particular religion, religious culture. It is realized in the society in organizations and institutions of the education system of religious confessions, in the family, in the media, cultural institutions, in the educational activities of other social institutions, institutions and individuals, including state and municipal educational institutions in accordance with their educational programs, curricula, and disciplines.

Religious education on world outlook fundamental is carried out on the ideological, spiritual and moral basis of this or that religion and is grounded on the worldview and way of life that has developed in this religious tradition. It is implemented in the organizations and institutions of the education system of religious confessions in the study of all educational disciplines, in the family, in the media, cultural institutions, in the educational activities of other social institutions, institutions and individuals, including state and municipal educational institutions. The determining factor is the right of free choice granted to students and (or) their parents (legal representatives), provided that the basic educational program of the institution is fulfilled and the legitimate rights and interests of all participants in the educational process are observed. The right to receive secular education in accordance with the beliefs adopted in the family, including religious ones, is recorded both in the international legislation recognized by our state and in the Russian legislation. It is important to note that any religious education, including the spiritual (professional religious education), is in fact not part of a religious cult, it does not provide for mandatory religious rituals, rituals in educational institutions or in the process of education [7].

It is obvious that any religious education should be carried out with the participation (directly or indirectly) of the relevant religious organization. This is necessary to ensure the identity as part of the actual content of knowledge about a particular religion, their source, undistorted and complete representation of all aspects of history, culture, way of life in this religious tradition, and to ensure the teaching of any knowledge on a particular religious worldview. Such participation can be the direct control of religious organizations for the content of education in schools, universities, etc., established by them directly or jointly with other founders or in the form of confessional expertise of the qualifications of teaching staff, curricula, textbooks, manuals, etc. used in any other educational institutions. For example, in the Russian Orthodox Church, such confessional expertise is conducted in authorized organizations (the Training Committee, the Synodal Department of Religious Education and Catechesis, the Diocesan Departments of Religious Education, etc.).

Thus, the leading criterion for the educational activity to study religion in the field of religious education is interaction with the corresponding religious organization. If such interaction is established and fixed in normative legal documents, the study of religion in any educational institution, including in the state and municipal, can be considered a form of religious education. This corresponds to the world practice.

\section{RELIGIOUS STUdIES EDUCATION AS A BASIC FORM OF STUDy OF RELIGION IN THE SECULAR STATE}

According to the Law of the Russian Federation "On Education", "The content of education shall promote mutual understanding and cooperation between people and peoples regardless of race, nationality, ethnicity, religion or social belonging, take into account the diversity of ideological approaches, promote the right of students to freely choose opinions and beliefs, provide the development of the abilities of each person, the formation and development of his personality in accordance with the spiritual and moral and sociocultural values adopted in the family and in society "(art. 12, par. 1) [8].

In accordance with this, it is obvious that the teaching of knowledge about religion in a secular school can be of three types: 
- Teaching the knowledge of religion as a doctrinal knowledge, on an alternative basis, in accordance with the choice of the student and his family (religious approach);

- Teaching knowledge about religion as a cultural tradition, significant along with other religious traditions (culturological approach);

- Philosophical approach, when knowledge of religion is taught as a worldview and meaningful problem, through questions of axiological and existential nature.

In our opinion, considering the regional socio-cultural diversity of the country, culturological (at the level of general education) and philosophical-worldview (at the level of vocational education) approaches should be a priority. Both of these approaches can be implemented within the framework of religious studies.

Modern religious studies are an interdisciplinary science, the subject of which is religion. Due to the interdisciplinary character, religious studies presuppose many approaches, the unity of which is conditioned by non-ideological and nonvalue orientation of research, which presupposes in a certain sense the distancing of the researcher from the subject of research. The scientific approach presupposes criticism of sources, as well as an unbiased critical analysis of theoretical constructions [9]. The latter does not at all suggest that a religious scholar must necessarily be an atheist; religious scholars can also engage in religious studies, it is important only to distinguish between theological and religious studies.

In modern Russian society, religious studies constitute the study of religion from the standpoint of science and various directions in philosophy, conducted without communication and interaction with religious organizations. It is this religious education that we have today, the main, the most developed secular education in the study of religion, religious culture, focused on the whole society.

Its main forms are:

- The study of religion in higher education institutions of all organizational and legal forms in accordance with the state educational standards of professional education (specialty "Religious Studies");

- The study of religion in the general education school in accordance with the state standards of general secondary education, educational programs, curricula and disciplines, including the teaching of religious studies courses for students and / or parents of the type "Religious Studies", "History religion "," Religions of the world", etc.

Modern Russian religious studies and the corresponding religious studies show worldview diversity. The general methodological basis of religious studies and, accordingly, the main difference from religious education, as a rule, are: scientific (objective) and ideological impartiality. In the presentation of information about religion and religious associations, religious education rests solely on the principles of scientific character and does not pursue the goal of developing a certain attitude toward religion among students (in general, to any specific confession).

At the same time, the problem is that these conditions de facto are not always observed and need to be clarified. Thus, scientific approach, understood as the consideration of scientific data on religion, cannot serve as a criterion for distinguishing religious studies from religious education, since it is not the exclusive prerogative of philosophical religious studies. Religious education also takes into account scientifically proven facts, indisputable conclusions of scientific research on religion. Of course, to the extent that scientific methods are generally applicable to the study of the religious side in the life of the individual and society and do not contradict the philosophical principles of a specific religion. Similarly, the consideration of religions from the standpoint of one or another direction in philosophy is not exhausted by the exposition of scientific facts but includes their theoretical interpretations and generalizations from the standpoint of this philosophical direction.

Thus, religious studies presuppose not only studying, acquaintance with factual data about religion in general and specific religious traditions and organizations, but also different worldviews, the different axiological origins of one or another view of religion. In modern Russian practice, these are mainly philosophical 'explanations' of religion, an assessment of the history and culture of religions from the positions of different directions and schools in philosophy, sociology, and historical science.

\section{CONCLUSION}

To summarize, I want to note that religious knowledge is necessary for modern man, but precisely as knowledge about religions, and not as a doctrinal knowledge. Historical and cultural acquaintance with religions, beginning with the oldest, ending with modern ones, includes the ethical aspect, contributes to the deepening of mutual understanding between peoples [10]. The practice of studying religion in modern Russian society, primarily in the education system, is:

- The study of religion by the methods of science and the corresponding education, i.e. the actual scientific religious studies as a totality of facts, observations, scientific generalizations attributed to religion in general, individual religions, religious associations in the past and modern times in sociology, history, archeology, ethnography, social geography, etc. (part of education in the field of relevant scientific disciplines);

- Philosophical religious studies, philosophical criticism of religion (philosophy of religion) - an explanation of the origin, development and characteristics of religion in general and different religious traditions from the standpoint of philosophical worldviews, concepts, theories, with the purpose of substantiating these worldviews, 
concepts, theories and their dissemination in society (part of philosophical education);

- 'Faith-based' religious studies, religious education of different religious confessions - the study of religion and religious culture in order to increase the level of knowledge about the religious worldview and culture of this type or the introduction of this religious tradition in one form or another, including apologetic explanations of all other religions from the standpoint of outlook and culture of this religious confession, conducted with the participation of organizations of religious affiliations.

Obviously, all these types of study of religion and related educational activities have specific goals, each of which is significant for society at large or some part of it and, therefore, they all have the right to exist.

However, the study of religion in schools and universities requires a balanced approach. It seems that in state educational institutions only religious, but not theological education is possible, which will inform the youth about the history of world religions, their dogmas, traditions and today's life of religious communities from scientific and objective positions.

The study of religion in state educational institutions should include the following points:

- Teaching should be based on modern scientific and methodological approaches;

- The provision of knowledge about the world and traditional religions for our country should help students understand the world, its culture and the spiritual side of human life;

- Knowledge of the foundations of traditional religions plays an important role in the formation, support and preservation of national identity, prevention of the ideology of extremism and intolerance;

- An important aspect of religious studies education is to support the humanistic worldview and moral development of students.

\section{REFERENCES}

[1] V.A. Tsvyk, Ethics of Higher School (on the example of the Russian University of Peoples 'Friendship) // Bulletin of the Russian University of Peoples' Friendship. Series Philosophy. - 2016, No. 3, pp. 9-18.

[2] O.G. Alieva, O.V. Savvina, M.V. Moiseenko, The crisis of national cultures in the era of globalization // Bulletin of the Russian University of Peoples' Friendship. Series Philosophy. - 2014, No. 2, pp. 83-91.

[3] The Law of the Russian Federation "On Education". M., 2012.

[4] I.E. Lapshin, A.A. Kosorukova, V.S. Mukhametzhanova, Social Ethics of Corporate Anthem// 3rd International Multidisciplinary Scientific Conference on Social Sciences \& Arts SGEM 2016. Albena, Bulgaria, AUG 24-30, 2016. Published by STEF92 Technology Ltd, Sofia, 2016, pp. 833-840.
[5] The Law of the Russian Federation "On Education". M., 2012; The Federal Law "On Freedom of Conscience and on Religious Associations". M., 1997.

[6] I.V. Metlik, The study of religion in the education system // Pedagogy. 2003, No.7, pp. 67-74.

[7] I.V. Tsvyk, The Problem of Truth in the Russian Spiritual and Academic Philosophy of the 19th Century. // Bulletin of Moscow University. Series 7: Philosophy. 2004, No. 2, p. 15.

[8] The Law of the Russian Federation "On Education". M., 2012.

[9] I.V. Tsvyk, I.E. Lapshin, Ethics of professional practice. In: 3rd International Multidisciplinary Conference on Social Sciences and Arts, SGEM 2016, pp. 487-494.

[10] Ethics of higher education / Tsvyk V.A., Tsvyk I.V. and others. Moscow: Publishing House of the PFUR, 2016, 210 p. 